\title{
Hvordan vurderer leger i spesialisering kvaliteten på spesialistutdanningen?
}

\author{
I 2012 ble det gjennomført en landsomfattende evaluering av spesialistutdanningen for leger i Norge som \\ omfattet alle sykehusspesialiteter.
}

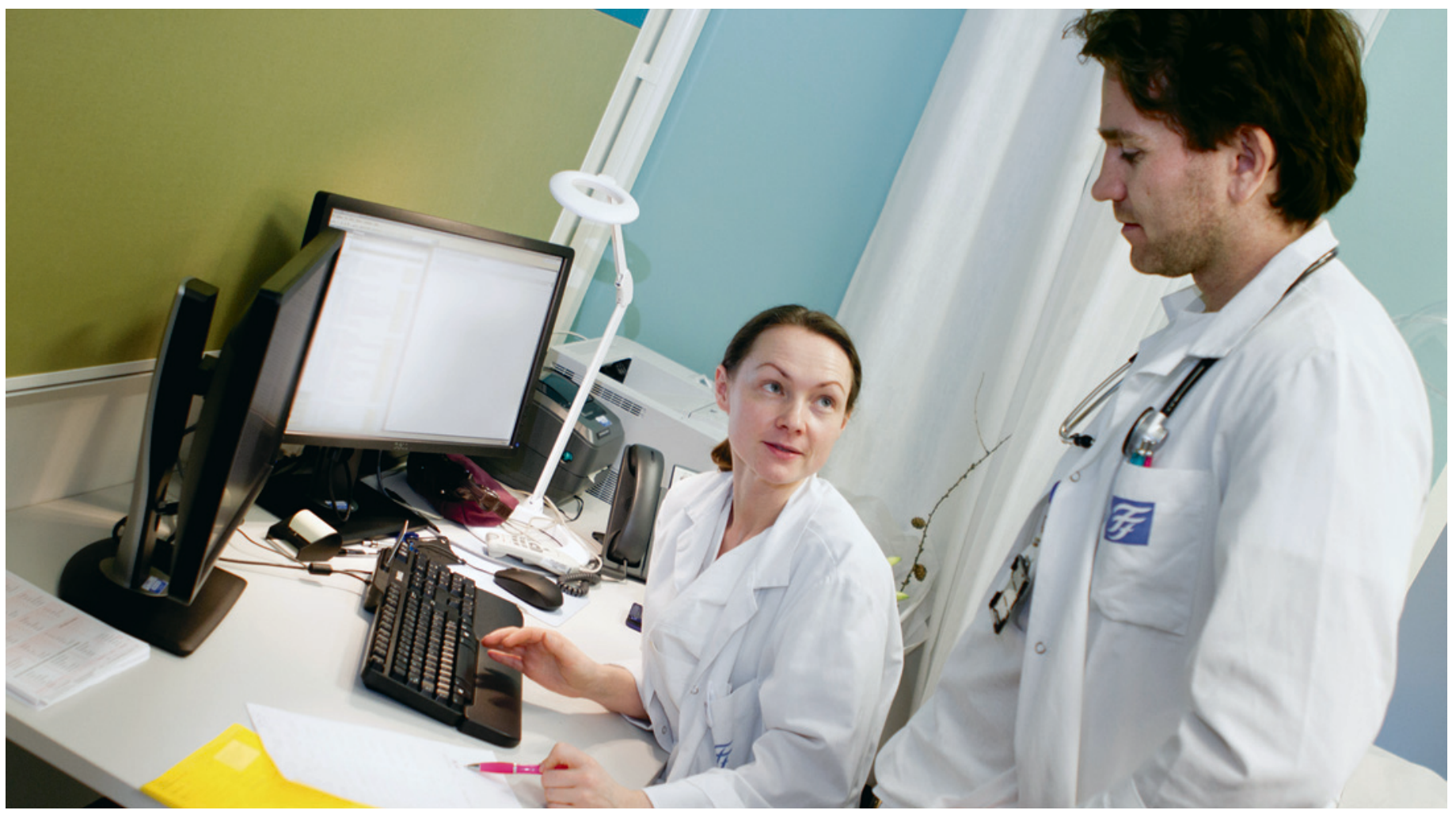

Illustrasjonsfoto: Ole Kristian Losvik

Den viktigste læringen for leger i spesialisering foregår på arbeidsplassen, som regel i sykehusavdelinger, klinikker og poliklinikker, gjennom internundervisning, supervisjon og veiledning fra ferdige spesialister. Med veiledning menes systematiske, planlagte samtaler mellom en fast oppnevnt veileder og en lege i spesialisering, mens supervisjon kjennetegnes av daglige en-til-ensituasjoner og instruksjoner mellom en lege i spesialisering og en spesialist. I denne studien ville vi undersøke hvordan legene selv opplevde nytten av og kvaliteten på utdanningen sin og om de får den utdanningen de har krav på (1).

\section{Forbedringspotensial}

Resultatene viste at legene i spesialisering samlet sett var godt fornøyde med undervisningen, mens både supervisjon og veiledning har et betydelig forbedringspotensial. Bare $49 \%$ av legene oppga at de hadde kom- met i gang med veiledning i løpet av første måned. Dette avviker dermed fra kravet i spesialistutdanningen. Kun en drøy tredel av legene har avsatt tid til veiledningssamtaler i tjenesteplanen, og en knapp tredel hadde veiledningssamtaler månedlig eller oftere. De fleste legene (86\%) opplevde tilstrekkelig supervisjon fra bakvakt når de trengte det. Samtidig opplevde bare $61 \%$ av legene at de fikk tilstrekkelig supervisjon i praktiske prosedyrer generelt, og kun $60 \%$ opplevde at de slapp tilstrekkelig til for å utføre praktiske prosedyrer i faget. Halvparten (52\%) oppga at de måtte jobbe utover avtalt normert arbeidstid for å få gjennomført de praktiske prosedyrene som de trengte for å få godkjent tjenesten. Legene som holdt på med en kirurgisk hovedspesialitet måtte signifikant oftere jobbe utover normert arbeidstid for å få gjennomført de praktiske prosedyrene enn leger innenfor andre fagområder.
Det kommer tydelig frem at det er vanskelig å få avsatt tid til både veiledning og supervisjon i en hektisk arbeidshverdag der de ansvarlige spesialistene på den ene siden skal produsere gode helsetjenester samtidig som opplæring av nye spesialister skal ivaretas.

\section{Cecilie Normann Birkeli}

cecilie.normann@legeforeningen.no

Cecilie Normann Birkeli (f. 1976) er rådgiver og prosjektleder ved Legeforskningsinstituttet.

\section{Litteratur}

1. Birkeli CN. Kvalitet koster. Om spenningen mellom spesialistutdanningen for leger og produksjon av helsetjenester. Masteroppgave i helsevitenskap. Trondheim: Norges teknisk-naturvitenskapelige universitet, 2013. 